\title{
Is this the Dawning of the Age of Surveillance? - Monitoring Offenders in New Zealand
}

\author{
KIM WORKMAN
}

\begin{abstract}
Over the last ten years, the New Zealand criminal justice system has moved inexorably toward embracing policies and legislation which favour offender surveillance over offender reintegration and rehabilitation. This article discusses the recent growth of surveillance legislation in New Zealand, the impact on the traditional norms and values of the criminal justice system, and the wider implications of becoming a "surveillance society." It argues that the introduction of surveillance has occurred in the absence of any scientific evidence for its effectiveness, that it has harmed our international human rights record, and impeded effective prisoner reintegration. It concludes by putting a case for a more comprehensive and evidencebased approach to prisoner and offender reintegration.
\end{abstract}

\section{Introduction}

Every breath you take

Every move you make

Every bond you break

Every step you take

I'll be watching you

"Every Breath You Take," lyrics by Sting.

In early November 2015, I appeared before the Social Services Select Committee to make a submission on the Child Protection (Sex Offenders Register) Bill, and argued that the legislation was flawed. The Chairperson commented that the Bill was not primarily about child protection and that the Police saw the legislation as a means of monitoring released child sex offenders; of "knowing where they are." I was caught off balance. The function of the Bill had changed even before it became law. Surveillance of released offenders had become an end in itself, rather than as a means of protecting children.

\section{The Growth of Surveillance Legislation}

Over the last ten years, the New Zealand criminal justice system has moved inexorably toward embracing policies and legislation which favour offender surveillance over offender reintegration and rehabilitation. Since 2002, eight pieces of surveillance legislation have been introduced into parliament, four of which are amendments to earlier legislation, and designed to either increase the punitiveness of existing legislation, expand its reach to include new classes of offenders, or apply additional conditions to existing sentence regimes. Five of the eight legislative measures have been introduced in the last two years.

As the surveillance industry takes hold, the policies and legislation which support it are steadily transforming the goals and norms of the corrections system, and enabling the goals of retribution, incapacitation, and general deterrence to supersede the goals of rehabilitation and specific deterrence. ${ }^{1}$ David Garland has described initiatives of this kind as contributing to a "culture of control" and a new systemic norm of surveillance. ${ }^{2}$ 


\section{Penal Surveillance - Panopticism as a Metaphor}

The belief that penal surveillance can prompt positive psychological change in offenders has long existed. In 1791, Jeremy Bentham designed a hypothetical prison called the Panopticon, in which prisoners imagine they are endlessly observed by an all-seeing guard. In his publication on the subject, Bentham promoted the concept of the Panopticon for much the same reasons that spur criminal-justice innovation today - a ballooning prison population and the need for a cheap solution with light manpower demands. Most of today's electronic surveillance initiatives are based on Bentham's psychology; proponents claim that constant surveillance and swift punishment will instigate behavioural change, and decrease criminality.

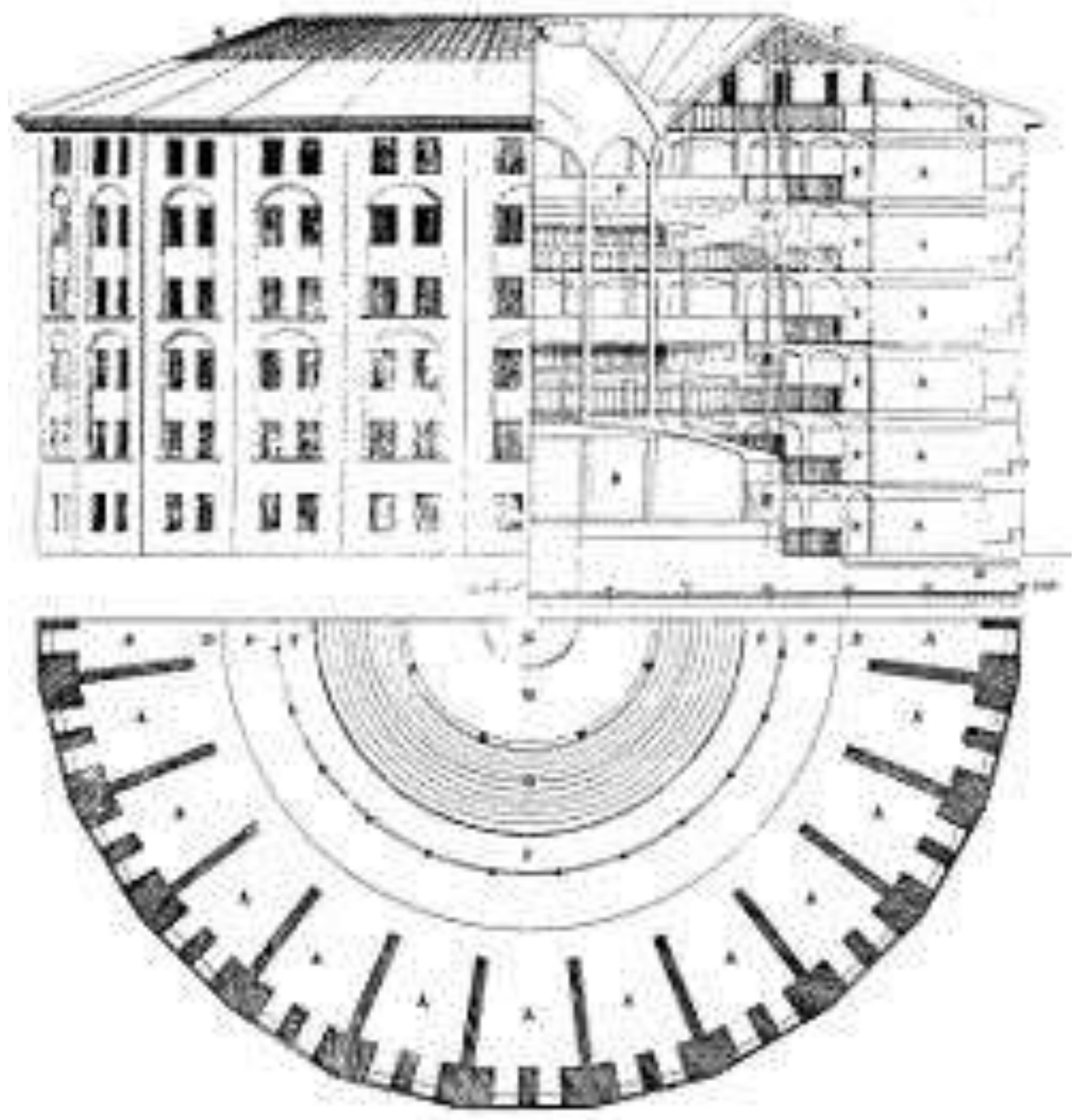

Figure 1. The Panopticon, "A mill for grinding men honest."3

The trick with the Panopticon was that the prisoners didn't know when they were being watched, and would have to act as though they were being watched at all times; thus effectively controlling their behaviour. Bentham described it as "obtaining power of mind over mind." It was cheaper than the prisons of his time, as it required fewer staff, and prisoners could also be 
used as menial labour, walking on wheels to spin looms or run a water wheel. This would decrease the cost of the prison and give a possible source of income. It all sounds familiar.

It was never built. The Irish and French governments were not interested, and after more than twenty years trying to convince the British government of its merits, Bentham abandoned the project. The idea of the panopticon was later invoked by Michel Foucault in his 1975 book, Discipline and Punish: The Birth of the Prison, as a metaphor for modern "disciplinary" societies and their pervasive inclination to observe and normalise. ${ }^{5}$

\section{The Changing Penal Environment-from Penal Welfarism to Punitiveness}

The rapid recent escalation toward surveillance as a major strategy for the control and supervision of offenders, both inside and outside the prison, should not catch us by surprisethe signs were there 30 years ago. The restructuring of the public sector in the 1980s facilitated the political formation of a more conservative political regime. There was growing opposition to policies that appeared to benefit the "undeserving poor," cynicism about welfare, and support for more aggressive controls for an underclass that were perceived to be disorderly, drug-prone, violent and dangerous. There was increasingly more emphasis on responding to public clamour than on responding to the expertise of criminal justice professionals and empirical research. ${ }^{6}$

In 2002, criminal justice legislation confirmed a range of measures that extended prisoners' sentences and restricted parole. The rate of imprisonment grew from 91 per 100,000 population in 1987 to 200 per 100,000 in 2010, in the face of a stable and slowly declining crime rate. Probation increasingly represented itself as punishment in the community, rather than a supportive social alternative to imprisonment. Its priority became the close monitoring of released offenders, which led to the more frequent return of offenders to custody. Prisons became more punitive, and more security-minded. Prisoners became less eligible for such privileges as release to work and family visits, and more likely to be described in official reports as culpable, deserving of punishment and sometimes dangerous. They were no longer clients in need of support, but risks to be carefully managed. Instead of emphasizing rehabilitative methods that met offenders' needs, the system emphasised effective controls that minimized costs and maximized security. Prisoners became objects rather than subjects.

The hardening political and penal environment was fertile ground for the re-emergence of ideas about the virtues of surveillance. Privatized and politicized industry increasingly invested in expansion of the electronic surveillance industry, and prison overcrowding and technological infrastructure advances instigated the rapid expansion of electronic monitoring technologies during the 1990s. ${ }^{7}$ In 2009, almost 100,000 GPS tracking units were in use in the United States, as compared to 230 in $1999 .{ }^{8}$

\section{From a Risk Centric Society to a Surveillance Society}

The obsession with risk avoidance manifested itself in legislative measures which extended the locus of control (and punishment) beyond prisons and into the wider community.

In 2003, the Parole (Extended Supervision Order) and Sentencing Amendment Bill introduced an extended supervision regime for sex offenders who had served a finite sentence. The Attorney General made clear that it breached the Bill of Rights Act on two counts. First, it was being applied retrospectively, in breach of Section 26(2), punishing the person twice for the same offence. Second, it introduced a special provision, to allow 24-hour electronic monitoring within a law enforcement context. That provision breached Section 21 of the Bill of Rights 
Act, relating to the right to be secure against unreasonable search, and in the Attorney General's view constituted unreasonable interference with a person's reasonable expectation of privacy.

The Act was passed, allowing orders to be made imposing a range of conditions and restrictions for up to 10 years on persons who have previously been convicted of certain sexual offences, and who had completed their sentence, including parole. It included residential restrictions in the nature of home detention for the first 12 months, and ongoing parole conditions such as regular reporting, participation in programmes, prohibitions on entering certain places or areas and, where necessary, electronic monitoring to ensure compliance.

In 2009 a further amendment was introduced, giving the Parole Board power to impose residential restrictions in the nature of electronically monitored home detention (but short of 24 hours) for up to ten years. The Attorney General again reported that this Bill was inconsistent with the Bill of Rights, not only by reason of its retrospective application, but also because the proposed condition amounted to arbitrary detention, under section 22 of the Bill of Rights, and significantly extended the restrictions on personal liberty the Board might law fully impose. The Bill was accorded urgency and passed by Parliament in one day, on the pretext that it was designed to close some loopholes in the existing legislation. The Green Party later complained that it was unaware of the Attorney General's adverse report on the legislation.

The 2014 Parole (Extended Supervision Orders) Amendment Bill, introduced in December 2014, made further amendments to the Parole Act 2002, enabling extended supervision orders to be renewed as often as needed, and expanding the scope of orders beyond high-risk child sex offenders to include high-risk sex offenders and high-risk violent offenders. The Bill also provided for courts to order the imposition of a special condition allowing intensive monitoring of offenders for the first 12 months of their order.

This "strengthening" and "tightening" was not in response to increases in offending. In the six years from 2008 to 2014, none of the 169 sex offenders placed on Extended Supervision Orders (ESO's) were reconvicted of a sexual offence. Notwithstanding, the enforcer (usually the Police or Corrections) sought support to "tighten" or "strengthen" the legislation. The state effectively engaged in "function creep," and shifted the purpose of legislation from a concern for public safety to one of additional punishment and detention of offenders.

The Public Safety (Public Protection Orders) Bill was also introduced in 2014, and provided for the recall to prison of offenders once their sentence was finished, if they were at very high risk of reoffending. Once again, submitters drew attention to the significant breaches of the Bill of Rights around the issues of double jeopardy, arbitrary detention, and limiting the offender's right of review to once every five years. Once again, they were ignored.

\section{The Impact on New Zealand's Approach to Human Rights}

Over the last eight years, there has been an incremental and expanding introduction of legislative measures that are fundamentally in conflict with the rule of law, to the extent that in 2013 the Law Society felt impelled to report this matter to the United Nations. ${ }^{9}$ It listed a series of recent acts that have allowed the Executive to use regulation to override Parliament, that deny citizens the right to legal representation and cancel their right to appeal to the courts to uphold their rights under the law. The Law Society also drew attention to the use of Supplementary Order Papers and urgency to avoid proper Parliamentary scrutiny of legislation. They expressed their concern that a number of bills formally declared by the Attorney-General to be in breach of the Bill of Rights had been enacted. 
This practise has continued unabated since 2013, and surveillance legislation has been a major contributor. New Zealand's reputation as a nation protective of its human rights has taken something of a battering. Collectively, this legislation speaks of a nation in which the right against search and seizure and the protections against arbitrary or unlawful interference of privacy is ignored. ${ }^{10}$ A nation that is prepared to punish offenders twice for the same offence and authorise arbitrary detention, in breach of sections 26 and 22 of the Bill of Rights. ${ }^{11} \mathrm{~A}$ nation that not only illegally denies prisoners the right to vote, ${ }^{12}$ but is prepared to subject them to disproportionately severe treatment, in contravention of Section 9 of the Bill of Rights, resulting in disparities between offenders that are not rationally based and result in grossly disproportionate sentencing. ${ }^{13}$

\section{Risk Management and the Power of Sanction}

Underlying this approach to "risk management" is the belief that released prisoners and offenders will respond best to the constant threat of sanctions. Turning that belief into policy has led to a range of sentence measures including electronic monitoring, intensive supervision (i.e., additional home and office visits), random drug testing, home confinement, extensive behaviour restrictions, strict curfews, and expanded lengths of supervision. The basic idea is that tough community controls can reduce recidivism by thwarting an offender's criminal instincts. $^{14}$

There is no evidence to support this idea. What evidence there is tells us that:

- Additional controls increase the probability that technical violations will be detected, leading to greater use of imprisonment, and higher taxpayer costs. Petersilia and Turner's nine-state random-assignment evaluation found no evidence that increased community surveillance deterred offenders from committing crimes. $^{15}$

- Power-coercive strategies are the least likely to promote internalization and longterm change. ${ }^{16}$ Kelman, for instance, discusses three means of changing behavior: change via compliance, change via identification, and change via internalization. ${ }^{17}$ Power and coercion may achieve instrumental compliance, Kelman says, but is the least likely of the three to promote "normative re-education" and long term transformation once the "change agent" has been removed. ${ }^{18}$

- Heavy-handed control tactics serve to undermine respect for the Probation Service. ${ }^{19}$ Parole conditions that include prohibitions against association with criminal associates, or against entering licensed premises, both of which are impossible to enforce, are often viewed as evidence that the entire parole process is a joke. Persons returning from prison with few resources and little hope become defiant when they are faced with a pile of sanctions. ${ }^{20}$ Constant threats that are not backed up can lead to a form of psychological inoculation. ${ }^{21}$

- Ex-prisoners consider they have paid their debt to society: when they "get out," they want to "be out." As Mobley and Terry write, "No one wants the separation of prison and parole more urgently than do prisoners. Any compromise or halfmeasure, any 'hoops' or hassles placed in their path, breeds resentment." Many would prefer to serve their full sentence in prison rather than be faced with high levels of supervision. ${ }^{22}$ 


\section{The Expansion of Electronic Monitoring}

Electronic Monitoring (EM) of offenders was introduced into New Zealand under the provisions of the Sentencing Act and the Parole Act, 2002. Extensive research internationally has failed to demonstrate a clear case for its effectiveness in reducing crime. A 2005 study into EM for moderate- to high-risk offenders by Renzema and others was recently cited by the Department of Corrections in support of the use of electronic monitoring. That report, however, concluded that applications of EM as a tool for reducing crime are not supported by existing data. ${ }^{23}$ The authors warn:

If EM continues to be used as it has been used, short-sighted governments will continue to waste taxpayer dollars for ideological reasons and political gain. Governments that choose to use EM in the future ought to use it to enhance other services that have a known effect on crime reduction. Those governments must test the marginal effects of EM, publish the results, and discontinue use of EM if it fails to provide quantifiable public benefits. Money spent on EM could be spent on empirically-tested programs that demonstrably protect our communities. ${ }^{24}$

There is still no convincing case for its use. In a recent 2012 article, Carney cautions:

After over twenty years of use, however, there is no real consensus on the viability of EM surveillance as a crime control tool. Studies, none of which can be considered comprehensive, show mixed results. If anything, the majority of EM surveillance programs have yet to unmistakably accomplish their objectives. ${ }^{25}$

Lack of evidence, however, has not dulled the government's appetite for "strengthening" and "expanding" the electronic monitoring regime. The Electronic Monitoring Amendment Bill, introduced in May 2015, proposes to apply electronic monitoring of offenders to those released from a sentence of imprisonment of merely two years or less and of offenders sentenced to intensive supervision, something forbidden in the earlier legislation. Corrections ignored the evidence against the effectiveness of electronic monitoring, and justified the measure on the basis that the measure would improve public safety by making authorities aware when offenders have failed to comply with conditions relating to their whereabouts; and argued as well that the Bill would deter those monitored from committing further offences, in cases where the offender is prohibited from entering areas associated with their risk of reoffending.

The potential scope of the proposed legislation is alarming. The Bill does not identify the type of offender who would be targeted by this legislation, or limit its application to a class of offender. According to the 2014 Corrections Calendar Year statistics, 5, 857 prisoners served two years or less, as follows:

Less than 6 months

6 months to 1 year

1 year to 2 years

It is highly unlikely that there are many in this group who constitute a high risk to public safety, and an examination of the types of offences committed by this group, suggest that the numbers would be very low. But if the history of Extended Supervision Orders is anything to go by, the new legislation is likely to capture a high number of offenders who do not constitute a risk to public safety. 
In an effort to justify the legislation, Corrections submitted that the legislation would be used to focus on three classes of offenders:

a) Family violence offenders who pose a high risk to their victims;

b) High-risk sex offenders;

c) Gang-affiliated offenders who pose a high risk to public safety.

Outside of appealing to public and political emotion, the rationale for targeting these three groups is highly questionable. Electronic monitoring for violent male parolees does not have any significant effect on the likelihood of a parolee being committed to prison during the follow up period or on the amount of time before recommitment to prison, and high-risk sex offenders are adequately dealt with through existing legislative measures. ${ }^{27}$

The proposal to utilise this measure for "gang-affiliated" offenders has the potential to expand the original legislation well beyond its basic intent. According to gang expert Dr Jarrod Gilbert, the 4,000 gang affiliates identified by the Police in its crime data, includes those who:

a) Were charged together with a New Zealand adult (meaning "patched") gang member for the same offence;

b) Had an identified familial tie with a New Zealand adult gang member;

c) Had an identified connection to a New Zealand adult gang member. ${ }^{28}$

If this is still how gang affiliates are defined, then the former Minister of Police's estimate that $28 \%$ of all prisoners are gang affiliates, provides a very large cohort that could qualify for electronic monitoring. ${ }^{29}$ The potential for net-widening is significant, particularly for Māori. Māori are being imprisoned at a rate six times that of non-Māori, and for Māori males born in 1975, it is estimated that 22 percent had a Corrections-managed sentence before their 20th birthday, and 44 percent had a Corrections-managed sentence by the age of $35 .{ }^{30}$ It is therefore likely that most Māori, especially those living in marginalised communities, will have familial connections to, or an identified connection with, gang members. Those living in poor communities have contact with gangs on a daily basis, at school, community events, and sporting and cultural activities. Others will be deemed to be gang members by virtue of their birthright. A growing number of young Māori lawyers and professionals, have at least one parent who is a patched gang member.

Legislation of this kind provides additional opportunity for the criminal justice system to punish offenders for non-compliance. For whānau and families from marginalised communities, compliance with parole conditions already presents a special challenge. The lack of private transport, an itinerant lifestyle, difficulty with employment and housing, and struggles with drug and alcohol dependency, can result in the parolee breaching, and ending up back in prison.

That is what has happened over the last ten years. In 2004, 774 persons were imprisoned for offences against Justice (which includes breaches of parole and probation conditions). By 2014 that had number was 1302, a 68\% increase. In 2004, 55\% (or 429) of that group were Māori). The proportion of Māori in that imprisoned group rose from 55\% (or 429) in 2004, to 61\% in 2014. In other words, when Corrections decides to target a population (e.g., "ex-offenders at risk of re-offending") based on crude definitions which imply but do not prove criminality (e.g., "gang-affiliated"), and when that definition disproportionately targets an ethnic group (e.g., Māori) that is in turn disproportionately represented in marginalised communities, it becomes even further disproportionately disadvantaged. When that happens, the state engages 
in structural discrimination. While Māori comprise 53\% of the prison population, they comprise $61 \%$ of those re-imprisoned for breach of parole.

\section{Risk Assessment-The Saving Grace?}

The one potentially redeeming characteristic of the legislation referred to thus far is that each of the offenders subject to the provisions of the legislation will be subject to a risk assessment process. There is still ongoing debate about the accuracy of risk assessment methodology; but without it, the Corrections system would be engaging in wild guess work.

Up until 1995, efforts to assess the future risk of sex offenders was fraught with difficulty. In the absence of any scientifically-based risk assessment process, it was extremely difficult to predict future offending with any degree of accuracy. ${ }^{31}$ The research literature up to 1995 indicated that in a high proportion of cases clinical predictions proved false. ${ }^{32}$

This view was reflected in a 1994 Report of the NZ Law Commission, chaired by Sir Kenneth Keith, which pointed out that:

Any consideration of community safety must recognise that detention is a serious exercise of state power. In assessing a proposed detention power, the New Zealand Bill of Rights Act 1990 is crucial, particularly its affirmation that detention must not be arbitrary. To forestall any question of arbitrariness, powers of detention should be based on principle and be demonstrably necessary. In the present context, any proposal for power to detain dangerous individuals must take into account that, although predicting dangerousness is possible to some extent, and necessary, it is also difficult. $^{33}$

That changed from around 1995 onwards, and New Zealand was an important part of that change. After undertaking a number of local research projects into the effective assessment and treatment of sex offenders, the Department of Corrections developed further an assessment/intervention program which had been used extensively in the Canadian correctional system. ${ }^{34}$ The model aimed to identify high-risk offenders, identify the manipulable psychosocial factors associated with an individual's offending, and deliver a psychological intervention in a way that met the capacities and learning styles of the individual concerned.

New Zealand Corrections undertook internal research to validate the Canadian offender management tools and then developed its own actuarial risk prediction tools. ${ }^{35}$ It went on from there to become a world leader in the area of sex-offender assessment and treatment. The field is still evolving, and as recently noted there is still a need to move beyond the standard model for the actuarial assessment of sex offenders. ${ }^{36}$

Notwithstanding ongoing concerns, scientific risk assessment is better than nothing. The Report of the Government Inquiry into Philip John Smith concluded that risk assessment was not being applied consistently, and recommended that the Department of Corrections:

- should continue to invest in risk-assessment capability and tools, including best practice intelligence approaches that enable it to better identify complex high-risk prisoners who are eligible for "outside the wire" activities;

- should ensure the planning of each prisoner's pathway through his or her sentence is documented, reviewed regularly, and developed in a risk-based and multidisciplinary way. ${ }^{37}$ 


\section{The Sex Offender's Register-Surveillance minus Evidence-based Risk Assessment}

In August 2015, three months after the changes to the Electronic Monitoring Amendment Bill were introduced (and before they were passed), the Child Protection (Child Sex Offender Register) Bill was introduced to Parliament, requiring all child sex offenders to register if they were aged 18 years or over when the offence was committed, were convicted of a qualifying offence, and sentenced to imprisonment, or sentenced to a non-custodial sentence and directed to be registered at the discretion of the sentencing Judge. Offenders sentenced to imprisonment would remain on the register for 8 years, 15 years, or life, depending on the qualifying offence committed.

All registered offenders, when residing in the community, will be required to provide a range of personal information to a central register administered by the New Zealand Police. The registered offender must update the information annually, within 72 hours of any change of details, and at least 48 hours prior to travel. This information will enable the Police and the Department of Corrections to use accurate and up-to-date information to assess and manage the risk to public safety posed by known child sex offenders living in the community.

This will not be a public register, but authorised staff employed by the Ministry of Social Development and Housing New Zealand Corporation would have limited access to the information on the register and would exchange relevant information in the interest of public safety. Other government agencies would be able to access relevant information on the Register through the existing Police Vetting Service. The Police and the Department of Corrections would be able to inform third parties that a person is on the register where this is considered necessary to protect the safety of at-risk parties.

There is widespread concern about the legislation. The Attorney-General reported to the House under section 7 of the Bill of Rights Act, concluding that the Bill is inconsistent with section 9 (disproportionately severe treatment or punishment) and section 26 (double jeopardy), and cannot be justified under section 5 of the Act. The Law Society shares these views and has further concerns about the Bill's inconsistency with the Bill of Rights Act. In its view, the Registers stigmatises sex offenders, which would have the perverse effect of increasing their propensity to re-offend by reducing their opportunities for reintegration. It was concerned that the legislation would contribute to the offender's social isolation, forcing them to confirm persistently their central identity as being that of a sex offender. Another alarming feature of the Bill is the absence of a review mechanism against the period of registration.

What the Bill does do, however, is confirm once again the central characteristics of surveillance legislation. First, there is no evidence of its effectiveness. The Attorney-General's report on the Bill notes the scarcity of evidence that child sex offender registers deliver significant benefits in terms of improved public safety. ${ }^{38}$

Second, it involves significant breaches of basic human rights, as outlined in the Attorney General's report, and the report of the Human Rights Commission.

Third, it is a waste of scarce criminal justice resources. The cost of the register over the next ten years is calculated at $\$ 164.054$ million, and it is estimated that it will result in the detection of 4 to 34 sex offences leading to conviction. ${ }^{39}$ The appropriation (or misappropriation) of criminal justice resources based on public demand and/or media recommendations has been 
extensively criticized for failing to meet the real needs of current or future victims. ${ }^{40}$ The cost of this measure cannot be justified in terms of expected outcomes.

Fourth, the legislation lends itself to future amendments and modifications, intended to "strengthen" or "tighten" the current proposal, not to make it more effective in protecting children. The potential for protecting children is already negligible-further amendments will inevitably be directed toward the further punishment and unlawful detention of offenders.

That has certainly been the experience with the UK sex offender register, in operation since 1997. By 2001, registrant compliance with the register was estimated at $97 \% .{ }^{41}$ Despite the high compliance rate, the register has repeatedly been repeatedly "strengthened" or "tightened" since 1997. The decision to do so appears to be taken by the Police, without any reason given for the change. ${ }^{42}$ Over the first ten years of the Register there were seven interventions when the register was "strengthened," or the authorities given greater powers over those on the register. The widely held view is that the UK legislation has now become less about child protection, and more about punishment.

\section{An Emerging Characteristic - the Abandonment of Scientific Risk Assessment}

It is now well established that individuals with sexual offence convictions differ in their risk for sexual reoffending, and can be reliably classified into different risk categories on the basis of static and dynamic risk factors.

As Dr Gwenda Willis points out, under the proposed Bill all individuals convicted of qualifying offences are subject to registration, though requirements concerning the length of time individuals must comply with registration requirements differ as a function of offence type. ${ }^{43}$ "Class 1 offences" (e.g., sexual violation of a young person under 16) earn lifetime registration, "Class 2 offences" (e.g., indecent act on a young person under 16) earn 15 years, and "Class 3 offences" (e.g., indecent assault on young person under 16) earn 8 years. Thus, the length of time that an individual is subject to registration requirements is determined based on the nature of a qualifying offence, and not on their risk of sexual reoffending.

By categorising individuals on the basis of offence type rather than risk for reoffending, the utility of the Register (if there is any) is seriously comprised. Under the Bill, many individuals with a high risk of reoffending will be subject to registration requirements for shorter periods of time than many individuals with a low risk of reoffending.

It is difficult to fathom what the Police and Corrections intend. As Wills comments, the NZ Police vouched that the Register would be supported by an offender risk management framework, that targets resources to where the risk of re-offending is greatest. ${ }^{44} \mathrm{I}$ am therefore perplexed as to why offender risk assessment has not been integrated into the Register. ${ }^{45}$

Not as perplexed as I am. After 20 years of taking a doctrinaire position on the "risk, needs, responsivity" framework, which drives most of Corrections rehabilitative efforts and thinking, it has chosen to abandon those principles in this proposed legislation.

In a supplementary submission to the Select Committee, I offered the following view:

The legislation currently before this committee assesses offenders risk on the basis of offence type, rather than their risk of reoffending. It takes New Zealand back to the days before 1995; and a predictive approach which is referred to these days as "correctional quackery." 46 


\section{Returning Offenders (Management and Information) Bill}

Two months later, and acting under urgency, parliament introduced and passed legislation to establish a regime for the identification and management of offenders returning to New Zealand after being sentenced to more than one year's imprisonment in an overseas jurisdiction. It was a response to changes in the Australian treatment of New Zealand offenders, and the influx of New Zealanders deported from Australia after being convicted of an imprisonable offence, and in some cases, serving a sentence of imprisonment.

Previously, most offenders returning to New Zealand were not subject to any formal supervision or interaction with the New Zealand Police. The new legislation requires such offenders to provide the Police with identifying information (including photographs and fingerprints). This would supplement any information obtained from other jurisdictions in order for Police to have a reliable record of the offender's identity and to establish, among other things, whether they qualify for management by the Department of Corrections as a "returning prisoner" under this Bill. Offenders whose conduct would amount to an imprisonable offence in New Zealand will also be required to provide the Police with a sample of their DNA for the DNA profile databank.

Returning prisoners will be managed in the community by the Department of Corrections on a comparable basis to offenders released with conditions from a sentence of imprisonment in New Zealand. Once the Commissioner of Police has identified an offender as meeting the criteria for a returning prisoner, and serves the offender with a determination notice to that effect, the offender will automatically be subject to the standard release conditions provided in the Parole Act 2002.

Offenders will have to be identified as returning prisoners within 6 months of their return to New Zealand. Corrections will also be able to apply to the District Court for special release conditions to be imposed on the returning prisoner (including, on an interim basis, in advance of his or her arrival if the court considers it immediately necessary). It was claimed by the Police that the management of returning prisoners will assist their rehabilitation and reintegration into New Zealand, and reduce their risk of reoffending.

For the second time in as many months, a scientifically-based risk-assessment process is abandoned. In this case, the length of time that the individual is subject to surveillance is based not on the nature of the qualifying offence (as in the Child Sex Offenders Register), but on the length of time they served during their previous term of imprisonment. There is no known correlation between an offender's future risk and the time spent in prison for their most recent conviction.

The view that there is no significant breach of human rights is not shared by members of the criminal justice community. As Justspeak points out, if a person was sentenced to six years imprisonment in Australia, served four years and was on parole for the final two and then deported to NZ after their parole had ended, they would be contacted by Corrections on their arrival and be given parole conditions for another 2 years. People are effectively being forced to serve an extra half sentence. ${ }^{47}$

Nor does the legislation allow for differences in sentencing for similar offences. If a New Zealander is charged with possession of cannabis in Indonesia and spends 4 years in prison, a further compulsory 2 years of parole-like conditions would apply on their return. This is a total 
of 6 years punishment for an offence that would only result in a maximum of 6 months of prison if it had occurred in New Zealand.

\section{Characteristics of Panoptic Legislation in New Zealand}

The recent pursuit of surveillance as a means of punishing and controlling offenders invites metaphoric comparison with the Panopticon. In 1965, American historian Gertrude Himmelfarb published an essay, "The Haunted House of Jeremy Bentham," in which she depicted Bentham's mechanism of surveillance as a tool of oppression and social control. ${ }^{48}$ Characteristically, surveillance legislation:

a) is based on a false assumption that constant surveillance and certain punishment will initiate behavioural change in offenders;

b) is introduced in the absence of any scientific basis for the effectiveness of surveillance measures, and in some cases, evidence that it is likely to increase reoffending;

c) moves from scientifically based risk assessment, to unscientific risk assessment based on sentence category, or length of their most recent sentence;

d) is justified on the basis that the introduction new technology is likely to create cost savings (in the absence of any rigourous cost/benefit analysis);

e) is in breach of the Bill of Rights Act and international human rights covenants;

f) is initially introduced on the pretext that it will protect children, or preserve public safety, but subsequently changes its function to one of additional and unlawful punishment (often by way of amendments to the Act) through increased denial of human rights, arbitrary detention and restrictions on personal liberty;

g) over time, is amended to increase the level of punitiveness, or expand its reach to include other classes of offenders, without any evidence that the additional "tightening" or "strengthening" is necessary to reduce reoffending.

\section{Is there Another Model that Works?}

The "Age of Surveillance" would seem to be upon us. Thirty years ago, such a prospect would have seemed inconceivable. At that time, criminal justice thinking was more in the "welfare reformist" mould, and Jeremy Bentham was regarded as a relic of the dark ages. Criminal justice professionals were more likely to reference Winston Churchill, who during his brief reign as Liberal Home Secretary in 1910, embarked upon an ambitious reform of the penal system. In his oft-quoted speech to Parliament in 1910, Churchill stressed the importance of making a conscious effort to rehabilitate.

We cannot impose these serious penalties upon individuals unless we must likely make a great effort and a new effort to rehabilitate men who have been in prison and secure their having a chance to resume their places in the ranks of honourable industry. The present system is not satisfactory. ${ }^{49}$

He believed that there should be a just proportion between crime and punishment, and that even convicted criminals had rights against the state. 
I have a great admiration for the way in which the police conduct the business of police supervision of prisoners who have been released on license. It is not a bit true to say they harry a man and hunt him down. At the same time, it is a great impediment to a man to have to go and report himself repeatedly to the police, and to have the police coming repeatedly inquiring after him, in obtaining his position in honest industry again.

Churchill proposed that civil society should take a prominent role in the rehabilitation and reintegration of prisoners:

... we should establish a new central agency of a semi-official character, half official members representing the authorities and half the representatives of all these prisoners' aid societies. That would combine official power with what I think essential: that there shall be an individual study of every case; that all convicts shall be distributed by the central agency between different prisoners' aid societies of all the different denunciations, and all the different charitable societies.

Churchill was clear that the Police should not be involved in the supervision and monitoring of released prisoners:

.... the whole business of police supervision shall be absolutely suspended and the whole system of ticket of leave come to an end completely; and that except in the case of refractory persons, a convict, when he leaves prison, will have nothing more to do with the police. They need not see them nor hear of them again, but will be dealt with entirely through the agency of these societies, working under the central body, whose only object will be to do the best for the convict.

We have now come full circle, with the Police now engaged in the surveillance of released prisoners.

What would these voluntary societies do? The clue we have is contained within Churchill's speech when he proclaimed belief in the possibility of redemption. He spoke of

an unfailing faith that there is a treasure if only you can find it, in the heart of every man - these are the symbols which in the treatment of crime and criminals mark and measure the stored-up strength of a nation, and are the sign and proof of the living virtue in it.

\section{Beyond the Panopticon and Churchill-Searching for a New Model}

When in 2004, New Zealand Corrections launched its first official prisoner reintegration strategy, it was based on the Canadian "risk, needs, responsivity" rehabilitation model, confidently predicting that the model would "tell the Department how to work with offenders, based on their risk of re-offending, their level of need, and responsivity factors." disregarded the role of community organisations, opting instead for the gradual and structured released of offenders, under Corrections control. In so doing, it spurned Professor Tony Ward's "Good Lives Model" (now highly regarded), and closed its corporate ears to the ongoing discussion and debate between "risk-based" and "strengths based" approaches, and between "what works" and "desistance-based" corrections. ${ }^{51}$ The lack of robust engagement, analysis and discussion is making it easier for Corrections to retreat from the principles espoused by Churchill, and develop its own version of the Panopticon, with an increased emphasis on monitoring and surveillance. 
Dogmatic and narrowly conceived adherence to the merits of psychological rehabilitation, and subsequent movement toward panoptic legislation, has meant that as a nation, we have failed to engage fully with the debate about at least three other forms of rehabilitation: legal, moral and social. They are equally important in the process of desistance against crime. There has been no analysis of new ideas about strategies and policies which are effective in transforming the lives of offenders:

To the extent that felons belong to a distinct class of status group, the problems of desistance from crime can be interpreted as problems of mobility-moving felons from a stigmatized status as outsiders to full democratic participation as stakeholders. $^{52}$

McNeil and others argue that rehabilitation is a social project as well as a personal one. ${ }^{53}$ Even then, it is about much more than re-education and re-socialisation; it raises profound political questions about the nature of citizenship, the relationship between citizenship, society and the state and about the proper limits of legitimate state power. Psychological rehabilitation on its own is insufficient to generate significantly lower levels of reoffending, as it is principally concerned with promoting positive individual-level change in the offender. Instead, we must develop the offenders' motivation, skill and capacities, so they can engage with the other three forms of rehabilitation. The problem we now have is that the over-emphasis on surveillance works actively to prevent that from happening.

The first of these concerns is the practical expression of Cesare Beccaria's 1764 concern with the "re-qualification" of citizens - and the "legal and judicial rehabilitation," i.e., when, how and to what extent a criminal record and the stigma that it represents can ever be set aside, sealed or suppressed. ${ }^{54}$ Maruna argues that efforts to sponsor rehabilitation and reform must address the collateral consequences of conviction, and its exclusionary or stigmatising effects, or be doomed to fail. ${ }^{55}$ Increased surveillance serves to do the opposite: it marks out the offender for special attention, for additional stigmatisation, and makes their integration into society extremely difficult. No efforts at individual rehabilitation will succeed, if legal and practical barriers to reintegration are left in place, especially in relation to labour market exclusion. ${ }^{56}$

McNeil contends that the barriers are not just legal, but are also moral and social. It is here that a solely psychological conception of rehabilitation absolutely fails. It offers no moral redress per se, as it operates only on the individual "offender," not on the conflict itself and not on the victim or the community. ${ }^{57}$ Reparation and reparative work, such as well-constructed community work programmes are capable of fulfilling these functions in a way that psychological rehabilitation cannot, which is a private business, and allows for the reemergence of more retributive and affective forms of justice. ${ }^{58}$ There is emerging evidence that electronic monitoring is starting to replace community work sentences, thus denying the offender opportunity for redemptive work.

Moral rehabilitation, however, is not solely the responsibility of the offender. The state has a reciprocal duty to support reintegration that rests on two principles. ${ }^{59}$ First, recognition of the extent to which the community and the state bear some complicity in permitting or exacerbating social inequality; they too, must make good. Second, even under a retributivist approach to punishment, the polity has the duty to make sure that the punishment ends and that there is no punishment beyond the law. The evidence for panoptic legislation is that offenders and their families endure the effects of punishment, both intended and unintended, in abandonment of this important principle. 
What remains after that is the concept of "social rehabilitation": the full restoration of the citizen's formal social status, i.e., the informal and universal social recognition and acceptance of the reformed ex-offender. Much more than the "science" of personal reform, it is the ultimate problem. In the current hostile correctional climate, of which surveillance legislation is a part, it is unachievable.

\section{Concluding Comment}

Once momentum of the kind described in this paper builds, it is nigh impossible to contain it. What is probably needed at this point is for the state to promote a national discussion which challenges the narrow position that the role of Corrections and the Police is to prevent crime or reduce reoffending. Rather, there needs to be a wider debate across the criminal justice sector, and indeed the public sector, on the question of what sort of social goods, and what kind of society, they exist to promote. If that debate is well constructed, it may lead to the view that there is more to the Police and Corrections contribution to society than that of minimising harm. Otherwise they will continue to dehumanise the recipients of their services as "bearers of risks or needs, rather than as citizens who may need some support to enjoy their rights and fulfil their obligations." 60

\footnotetext{
${ }^{1}$ Roger K. Warren, "Evidence-Based Sentencing: The Application of Principles of Evidence-Based Practice to State Sentencing Practice and Policy," USF Law Review 43, no. 3 (2009): 585.

${ }^{2}$ David Garland, The Culture of Control: Crime and Social Order in Contemporary Society (Chicago: University of Chicago Press, 2001).

${ }^{3}$ Jeremy Bentham, Memoirs Part I and Correspondence, in The Works of Jeremy Bentham, ed. John Bowring, vol. 10 (Edinburgh: William Tait, 1843).

${ }^{4}$ Ibid.

${ }^{5}$ Michel Foucault, Discipline and Punish: the Birth of the Prison (New York: Random House, 1975).

${ }^{6}$ Kim Workman, "Politics and Punitiveness - Limiting the Rush to Punish" (paper presented at the conference of the Australian \& New Zealand Association of Psychiatry, Psychology and Law, and at the conference "The Rising Punitiveness," of the Royal Australian \& New Zealand College of Psychiatrists (Faculty of Forensic Psychiatry), Wellington, 17-19 November, 2011. Available online at

http://www.rethinking.org.nz/assets/Papers\%20and\%20Presentations/Limiting_the_Rush_to_Punish.p df, 20.

${ }^{7}$ Marsha Weissman, "Aspiring to the Impracticable: Alternatives to Incarceration in the Era of Mass Incarceration," New York University Review of Law and Social Change 33, no. 2 (2009): 235, 262.

${ }^{8}$ Bureau of Justice Assistance, "Offender Supervision with Electronic Monitoring," in Technology:

Community Corrections Resource, 2nd ed. (2009): 48-63. Available online at http://www.appanet.org/eweb/docs/APPA/pubs/OSET 2.pdf; Anthony C. Thompson, Releasing Prisoners, Redeeming Communities, Reentry, Race and Politics (New York: New York University, 2009), 9-26.

${ }^{9}$ New Zealand Law Society, Human Rights and Privacy Committee, "Submission to the $18^{\text {th }}$ Session of the Human Rights Council: Shadow Report to New Zealand's $2^{\text {nd }}$ Universal Periodic Review." Available online at http://www.lawsociety.org.nz/ data/assets/pdf file/0006/68541/United-Nations,Universal-Periodic-Review-17-6-13.pdf.

${ }^{10}$ Criminal Investigation (Bodily Samples) Amendment Act 2009.

${ }^{11}$ Parole (Extended Supervision Orders) Amendment Act 2009.

${ }^{12}$ Electoral (Disqualification of Sentenced Prisoners) Amendment Act 2010.

${ }^{13}$ Sentencing and Parole Reform Act 2010.

${ }^{14}$ Diana Gordon, The Justice Juggernaut: Fighting Street Crime, Controlling Citizens (New Brunswick, NJ: Rutgers University Press, 1991); Francis T. Cullen, "Rehabilitation and Treatment
} 
Programs," in Crime: Public Policies for Crime Control, ed. J. Q. Wilson and J. Petersilia, (Oakland, CA: Institute for Contemporary Studies, 2002), 253-89.

${ }^{15}$ Joan Petersilia and Susan Turner, "Intensive Probation and Parole," in Crime and Justice: An Annual Review of Research, Vol. 19, ed. M. Tonry (Chicago, IL: University of Chicago Press, 1993), 281-335.

${ }^{16}$ Robert Chin and Kenneth D. Benne, "General Strategies for Effecting Changes in Human Systems," in The Planning of Change, ed. W. G. Bennis, K. D. Benne, R. Chin, and K. Corey, 3rd ed. (New York: Holt, Rinehart and Winston, 1976), 22-44.

${ }^{17}$ Herbert C. Kelman, "Compliance, Identification and Internalization: Three Processes of Opinion Change," Journal of Conflict Resolution 2 (1958): 51-60.

${ }^{18}$ Anthony E. Bottoms, "Compliance and Community Penalties," in Community

Penalties: Change and Challenges, ed. A. Bottoms, L. Gelsthorpe, and S. Rex (Cullompton:

Willan, 2000), 87-116.

${ }^{19}$ Tom R. Tyler, Robert J. Boeckmann, Heather J. Smith and Yuen J. Huo, Social Justice in a Diverse Society (Denver, CO: Westview Press, 1997).

${ }^{20}$ Lawrence W. Sherman, "Defiance, Deterrence, and Irrelevance: A Theory of the Criminal Sanction," Journal of Research in Crime and Delinquency 30 (1993): 445-73; Thomas Blomberg and Karol Lucken, "Stacking the Deck by Piling Up Sanctions: Is Intermediate Punishment Destined to Fail?" The Howard Journal 33, no. 1 (1994): 62-80.

${ }^{21}$ Mark Colvin, Francis T. Cullen, and Thomas M. Vander Ven, "Coercion, Social Support, and Crime: An Emerging Theoretical Consensus," Criminology 40 (2002): 19-42.

${ }^{22}$ Alan Mobley and Charles Terry, Dignity, Resistance and Re-entry: A Convict Perspective. Unpublished manuscript, 2002.

${ }^{23}$ Marc Renzema and Evan Mayo-Wilson, "Can Electronic Monitoring Reduce Crime for Moderate to High-Risk Offenders?” Journal of Experimental Criminology 1 (2005): 215-37.

${ }^{24}$ Ibid., 233.

${ }^{25}$ Molly Carney, "Correction through Omniscience: Electronic Monitoring and the Escalation of Crime Control," Washington University Journal of Law and Policy 40 (2012): 279. Available online at http://openscholarship.wustl.edu/law_journal_law_policy/vol40/iss1/8.

${ }^{26}$ Statistics New Zealand, "Annual Sentenced Prisoner Population for the Latest Calendar Years." Available at: http://nzdotstat.stats.govt.nz/wbos/Index.aspx? DataSetCode=TABLECODE7324.

${ }^{27}$ M. A. Finn and S. Muirhead-Steves, "The Effectiveness of Electronic Monitoring with Violent Male Parolees," Justice Quarterly 19, no. 2 (2002): 307.

${ }^{28}$ Jarrod Gilbert, "The Queensland Anti-Bikie Laws Go to Court-Politics on Trial." Available at http://www.jarrodgilbert.com/blog/archives/09-2014.

${ }^{29}$ Ibid.

${ }^{30}$ Ministry of Justice, personal communication with the author, 5 May, 2011.

${ }^{31}$ J. Monahan, "The Prediction of Violent Behaviour: Toward a Second Generation of Theory and Policy," American Journal of Psychiatry 141 (1984): 10.

${ }^{32}$ C. Greenland, "Dangerous Sexual Offender Legislation in Canada, 1948-77: An Experiment that Failed," Canadian Journal of Criminology 26, no. 1 (1984): 1-11; C. Slobogin, "Dangerousness and Expertise," University of Pennsylvania Law Review 133 (1984): 97.

${ }^{33}$ Law Commission [New Zealand], Community Safety: Mental Health and Criminal Justice Issues, Report No. 30 (Wellington, 1994).

${ }^{34}$ D. A. Andrews and J. Bonta, The Psychology of Criminal Conduct (Cincinnati, OH: Anderson Publishing Company, 1994).

${ }^{35}$ L. Bakker, D. Riley, and J. O'Malley, The Identification of High Risk Offenders (Christchurch: Department of Justice, 1995).

${ }^{36}$ David Thornton, R. Karl Hanson, and Leslie Helmus, "Moving Beyond the Standard Model for the Actuarial Assessment of Sexual Offenders," California Coalition on Sexual Offending Quarterly

Newsletter, Perspectives (Spring 2010). Available at https://ccoso.org/featured-articles; see also A. J. R. Harris and R. K. Hanson, "Clinical, Actuarial and Dynamic Risk Assessment of Sexual Offenders: Why do Things Keep Changing?” Journal of Sexual Aggression 16 (2012): 296-310. 
${ }^{37}$ John Priestly and Simon Murdoch, Government Inquiry into Matters Concerning the Escape of Phillip John Smith/Traynor (Wellington: State Services Commission, 2015), 10. Available at http://www.ssc.govt.nz/sites/all/files/report-inquiry-escape-phillip-smith-traynor-aug2015.pdf. ${ }^{38}$ Report of the Attorney-General under the New Zealand Bill of Rights Act 1990 on the Child Protection (Child Sex Offender Register) Bill (6 May 2015), 33.

${ }^{39}$ New Zealand Police and Department of Corrections, Regulatory Impact Statement: Child Protection Offender Register and Risk Management Framework Agency Disclosure Statement (6 June, 2014).

${ }^{40}$ C. Critcher, "Media, Government and Moral Panic: The Politics of Paedophilia in Britain 2000-1," Journalism Studies 3, no. 4(2002): 521-35; C. Greer, Sex Crime and the Media: Sex Offending and the Press in a Divided Society (Cullompton: Willan, 2003); J. Kitzinger, "The Ultimate Neighbour from Hell? Stranger Danger and the Media Framing of Paedophiles," in Social Policy, the Media and Misrepresentation, ed. B. Franklin (London: Routledge, 1999), 207-21; J. Kitzinger, Framing Abuse: Media Influence and Public Understanding of Sexual Violence Against Children (London: Pluto, 2004); J. Kitzinger, "Media Coverage of Violence Against Women and Children," in Women and the Media: International Perspectives, ed. K. Ross and C. M. Byerly (London: Blackwell, 2004), 13-38.

${ }^{41}$ Home Office/Scottish Executive, Consultation Paper on the Review of Part 1 of the Sex Offenders Act 1997, (London/Edinburgh, 2001): 12.

${ }^{42}$ Terry Thomas, "The Sex Offender 'Register': A Case Study in Function Creep," The Howard Journal 47, no 3 (July 2008): 227-37.

${ }^{43}$ Gwenda Wills, Submission to Social Services Select Committee on the Child Protection (Child Sex Offenders Register) Bill 2015.

${ }^{44}$ NZ Police Regulatory Impact Statement (2014), paragraph 12.

${ }^{45}$ Wills, Submission.

${ }^{46}$ Kim Workman, Supplementary Submission from Robson Hanan Trust to Social Services Select Committee on the Child Protection (Child Sex Offenders Register) Bill 2015.

${ }^{47}$ Justspeak, Media Release, "New Act for Returning Offenders Breaches Rights" (20 November, 2015). Available at http://www.scoop.co.nz/stories/PO1511/S00317/new-act-for-returning-offendersbreaches-rights.htm.

${ }^{48}$ Gertrude Himmelfarb, "The Haunted House of Jeremy Bentham," in Ideas in History: Essays Presented to Louis Gottschalk by his Former Students, ed. Richard Herr, Harold T. Parker (Durham, NC: Duke University Press, 1965).

${ }^{49}$ Commons and Lords Hansard, Official Report of Debates in Parliament, 20 July, 1910. Available online at http://hansard.millbanksystems.com/commons/1910/jul/20/class-iii. Subsequent quotations from Churchill ibid.

${ }^{50}$ Department of Corrections, "Presentation at the Community Forum on Offender Reintegration" (13 May, 2004).

${ }^{51}$ D. Andrews, J. Bonta, and J. Wormith, "The Risk-Need Responsivity Model: Does the Good Lives Model Contribute to Effective Crime Prevention?" Criminal Justice and Behavior 38 (2011): 735-55; Tony Ward, Pamela M. Yates, and Gwenda M. Willis, "The Good Lives Model and the Risk Need Responsivity Model: A Critical Response to Andrews, Bonta, and Wormith (2011)," Criminal Justice and Behavior 39 (2012): 94.

${ }^{52}$ C. Uggen, J. Manza, and M. Thompson, "Citizenship, Democracy and the Civic Reintegration of Criminal Offenders," Annals AAPSS 605 (2006): 281-310.

${ }^{53}$ McNeil, "A Desistance Paradigm."

${ }^{54}$ C. Beccaria, On Crimes and Punishment, Trans. H. Pallouci (Indianapolis: Bobbs-Merrill, 1963 [1764]).

${ }^{55}$ S. Maruna, "Reentry as a Rite of Passage," Punishment and Society 13 (2011): 3-28.

${ }^{56}$ P. McGuiness, F. McNeil, and S. Armstrong, The Use and Impact of the Rehabilitation of Offenders Act (1974): Final Report (Glasgow: Scottish Centre for Crime and Justice Research, University of Glasgow, 2013).

${ }^{57}$ L. Zedner, "Reparation and Retribution: Are they Reconcilable?" The Modern Law Review 57 (1994): 228-50. 
${ }^{58}$ A. Frieberg, "Affective Versus Effective Justice: Instrumentalism and Emotionalism in Criminal Justice," Punishment and Society 3, no. 2 (2001): 265-78.

${ }^{59}$ F. McNeil, "Punishment as Rehabilitation," in Encyclopedia of Criminology and Criminal Justice, ed. G. Bruinsma and D. Weisburd (New York: Springer Science and Business Media, 2013), 41954206.

${ }^{60}$ S. Kirkwood and F. McNeill, "Integration and Reintegration: Comparing Pathways to Citizenship Through Asylum and Criminal Justice," Criminology and Criminal Justice 1, no. 5 (2015): 511-26. 